Full-text Available Online at https://www.ajol.info/index.php/jasem http://ww.bioline.org.br/ja
J. Appl. Sci. Environ. Manage.

Vol. 23 (8) 1549-1555 August 2019

\title{
In-Vitro Antibacterial Activity of Lantana trifolia Flower Extracts on Bacterial Isolates from Wounds
}

\author{
AGWU, EJ \\ Department of Zoology and Environmental Biology, Faculty of Biological Sciences, University of Nigeria, Nsukka \\ Email: ekenma.agwu@unn.edu.ng
}

\begin{abstract}
This study investigated the phytochemical constituents and antibacterial activities of Lantana trifolia flower extracts against bacterial isolates from surgical and diabetic wounds of patients. Phytochemical investigation was done by standard procedure, antimicrobial screening by agar well diffusion method and antibiotics susceptibility of isolates by Kirby-Bauer disc diffusion test. Phytochemicals present include flavonoids, tannins, phenylethanoid glycosides, reducing sugars, terpenoids, saponins, anthraquinones alkaloids and steroids. Bacterial wound isolates were mainly gram +ve and include Staphylococcus aureus, S. epidermidis, Enterococcus faecalis, Corynebacterium sp., Enterobacter aerogenes, Pseudomonas aeruginosa, Mycobacterium sp. and Escherichia coli. Inhibition diameter was concentration. The range of inhibition diameter was significantly $(\mathrm{P}<0.05)$ lower in the aqueous extract $(15.2 \pm 1.5$ to 35.5 $\pm 0.9 \mathrm{~mm})$ than the ethanolic $(28.3 \pm 3.4$ to $49.1 \pm 8.9 \mathrm{~mm})$. Antibacterial activity occurred at very low concentrations $(18.75 \mathrm{mg} / \mathrm{ml})$ for ethanolic extract only. The most $L$ trifolia extract sensitive bacterial isolate was $S$. aureus $(35.5 \pm 0.9 \mathrm{~mm}$ and $49.1 \pm 8.9 \mathrm{~mm}$ for aqueous and ethanolic extracts respectively at $300 \mathrm{mg} / \mathrm{ml}$ ), while the least sensitive were Corynebacterium sp. $(15.2 \pm 1.5 \mathrm{~mm})$ and Mycobacterium sp. $(28.3 \pm 3.4)$ at $300 \mathrm{mg} / \mathrm{ml}$ for aqueous and ethanolic extracts respectively. The minimum inhibitory concentration was lower for ethanolic extract, $18.75 / \mathrm{ml}$ to $37.5 \mathrm{mg} / \mathrm{ml}$ than the aqueous extract ( 37.5 to $150 \mathrm{mg} / \mathrm{ml}$ ). The minimum bacterial concentration range from $37.5 \mathrm{mg} / \mathrm{ml}$ to $150 \mathrm{mg} / \mathrm{ml}$ for ethanolic extract and 75 to $300 \mathrm{mg} / \mathrm{ml}$ for aqueous extract. S. aureus was the most antibiotic resistant strain $(72 \%)$, while P. aeruginosa and Mycobacterium sp. were the least resistant (9.1\%) strains. L. trifolia was more bacteriostatic than the most effective antibiotics, Ciprofloxacin, Rocephin, Nitrofurantoin, and deserves further investigation.
\end{abstract}

DOI: https://dx.doi.org/10.4314/jasem.v23i8.20

Copyright: Copyright (C) 2019 Agwu. This is an open access article distributed under the Creative Commons Attribution License (CCL), which permits unrestricted use, distribution, and reproduction in any medium, provided the original work is properly cited.

Dates: Received: 09 July 2019; Revised: 18 August 2019; 24 August 2019

Keywords: Phytochemical screening, Bacteriostatic activity, Lantana trifolia, Resistance, Wounds

Microorganisms especially bacteria are the causative agents of wound infections, which is an important cause of morbidity in surgical and diabetic patients (Giacometti et al., 2000; Mohammed et al., 2013). The widespread use of antibiotics to fight infections, has resulted in increased bacterial resistance to existing drugs, a development which threatens public health (Munita and Arias, 2016). Bacterial adaptation to the antibiotics attack, has led to immense genetic plasticity amongst the bacterial pathogens, in the form of mutational adaptations, acquisition of genetic materials or alteration of gene expression, producing resistance to virtually all antibiotics currently in use in clinical practice. The continued evolution of bacterial resistance to currently available antibiotics has necessitated the search for novel and effective antimicrobial compounds. Two major indices that determine the potency of the prospective antimicrobial candidate are the minimum inhibitory concentration (MIC) and the minimum bacterial concentration (MBC). Minimum inhibitory concentration (MIC) is the lowest concentration of a chemical, usually a drug, which prevents visible growth of bacteria. $\mathrm{MBC}$ on the other hand, is the lowest concentration of an antibacterial agent required to kill a particular bacterium (Okigbo and Mmeka, 2008). The best alternative for new microbial agents with minimal side effects, are natural products of plant origin. Medicinal herbs are readily available, cheap, efficacious and quite popular in developing countries (Preethi et al., 2010). Lantana trifolia Linn. (Family: Verbenaceae), was chosen for this work based on the ethnobotanical evidence of the plant world-wide. It is a terrestrial, evergreen aromatic and hairy shrub. Its resilient nature makes it invasive, dominating native species as a weed and widely distributed in the pantropics (Salada et al., 2015).It is used in many parts of the world in conventional medication for the cure of different human diseases, possessing analgesic, antimalarial, antifungal, antibacterial, enzyme inhibition, hepatotoxic, insecticidal and nematicidal properties (Sousa and Costa, 2012). It is a rich source of terpenoids and saponins (Sousa and Costa, 2012; Nalubega et al., 2013). In this study, the bacterial 
spectrum of surgical and diabetic wounds were investigated, phytochemical and antibacterial screening of aqueous and ethanolic flower extracts of L. trifolia were conducted.

\section{MATERIALS AND METHODS}

Plant Materials: The L. trifolia red flowers were collected from a building site bush in the University of Nigeria, Nsukka campus and identified by the Department of Plant Science and Biotechnology in the university. The flowers were washed with clean water to remove dirt and drained, oven- dried at $45^{\circ} \mathrm{C}$ for 5 days and ground into a powder using a milling machine (Noris and Poole, England). The powdered flower were kept in labelled sterile containers until when required.

Extraction of Crude plant Extracts: A modified method of Idris et al. (2009) was used. Four hundred gram $(400 \mathrm{~g})$ of the ground plant material was macerated in I litre each of distilled water and $99.9 / 100 \%$ ethanol for $24 \mathrm{~h}$. The solutions were filtered through a sieve to remove debris and the filtrates were then filtered through Whatman no. 1 filter paper. The final filtrates were evaporated in a water bath at $48^{\circ} \mathrm{C}$ to get the crude extracts. The crude aqueous and ethanolic extracts of the plant, were stored at $4^{\circ} \mathrm{C}$ until required for the phytochemical and antibacterial analysis. The $400 \mathrm{~g}$ yielded and $119.2 \mathrm{~g}$ and $51.2 \mathrm{~g}$ representing $29.8 \%$ and $12.8 \%$ yield for ethanolic and aqueous extracts respectively of $L$. trifolia after the extraction process.

Preparation of Concentration of Plant Extract: Seven hundred and fifty milligrams (750mg) of both ethanol and aqueous leaf extracts of L. trifolia were added to $5 \mathrm{ml}$ of ethanol and distilled water respectively to give a concentration of $300 \mathrm{mg} / \mathrm{ml}$. Other concentrations of $150,75,37.5$, and $18.75 \mathrm{mg} / \mathrm{ml}$ were prepared by dilution method as described by Evbuomwan et al. (2017).

Test Bacterial Isolates: Wound swabs were collected from 120 patients with infected diabetic wounds and surgical sites. To avoid contaminating the swab with skin flora, pus or necrotic tissue, the wound was thoroughly cleansed with $60-120 \mathrm{ml}$ sterile normal saline prior to taking the sample. Sterile gauze was used to remove excess saline from the wound surface and the wound swabs were collected using sterile swab by swabbing at the middle of the wound. When there were two or more wounds in the same location, separate swabs were used for each wound. A swab moistened with sterile normal saline was rolled deep in the wounds and inserted immediately into a tube containing Stuart's transport media for preservation of microbes and then transported to the laboratory. Wound swabs were streaked on Blood Agar (BA) and MacConkey Agar (MCA) plates and incubated aerobically for $18-24 \mathrm{~h}$ at $37^{\circ} \mathrm{C}$. They were then observed for bacterial growth. Plates with no growth and with growth were re-incubated for another 18$48 \mathrm{~h}$ for isolation of bacteria that require extended incubation (slow growers) (Giacometti et al., 2000). Pure isolates were identified according to their morphological characteristics and reactions to biochemical tests.

Standardization of inoculum: Isolated bacteria were sub-cultured onto fresh plates of MacConkey or blood agar depending on the bacteria type, and incubated aerobically at $37^{\circ} \mathrm{C}$ for $18-24 \mathrm{~h}$. Colonies from these plates were suspended in Mueller-Hinton broth (Oxford, UK) to a turbidity matching 0.5 McFarland standard $\left(10^{8} \mathrm{~m} \mathrm{cfu} / \mathrm{ml}\right)$. Mueller-Hinton agar was then used for antibacterial assay. All the broth cultures were incubated at $37^{\circ} \mathrm{C}$ (Aibinu et al., 2007).

Antimicrobial assay: After the isolation and identification of the bacteria, antibacterial screening of the aqueous and ethanolic extracts of L. trifolia flowers was done using agar diffusion method. $0.2 \mathrm{mls}$ of standard inoculum suspensions of the isolated bacteria were used. Each labelled plate was uniformly seeded with a test organism by means of sterile swab stick rolled in the Mueller-Hinton culture medium. A well of uniform size was made in each plate. 300,150 , $75,37.5$ and $18.75 \mathrm{mg} / \mathrm{ml}$ concentrations for aqueous and ethanolic extracts were dropped in each well to fullness. Each plate was kept in the refrigerator for $1 \mathrm{~h}$ to allow the extracts to diffuse into the culture medium, while the immediate growth of the organism was stopped from taking place. These plates were then incubated at $37^{\circ} \mathrm{C}$ for $48 \mathrm{~h}$. The zones of inhibition around the wells were measured in millimetre. Antibiotics such as Ciprofloxacin (2mls of $1 \%$ solution), distilled water and ethanol solvent with test organisms were placed in a well on each plate along with the test extracts as control. This was done in triplicates.

Determination of minimum inhibitory concentration: This was calculated in millimetres from readings on the culture plates after incubation.

$\begin{array}{ccc}\text { Determination } & \text { of minimum bactericidal } \\ \text { concentration: } & \text { Doubling diffusion } & \text { containing }\end{array}$ different concentrations as used in MIC determination was carried out thus: to a $0.5 \mathrm{ml}$ extract, $0.5 \mathrm{ml}$ of sterile distilled water was dispensed, from this test tube labelled ' 1 ', $0.5 \mathrm{ml}$ of the mixture was taken and dispensed to a test tube labelled ' 2 ' containing $0.5 \mathrm{ml}$ 
sterile distilled water, this was done twice and from the last test tube labelled ' 4 ', $0.5 \mathrm{ml}$ of the mixture was taken so that the mixture remained as $0.5 \mathrm{ml}$. This was done for the different concentrations of the plant extracts. To the tubes containing different concentrations of the extracts ( 300 to $18.75 \mathrm{mg} / \mathrm{ml}$ ) 0.5 $\mathrm{ml}$ of each test organism was added. Samples were streaked from the tubes onto Mueller-Hinton agar plates to determine the minimum concentration of the extract required to kill the organisms. These concentrations were indicated by failure of the extract to kill the organisms. The lowest concentration that prevented bacterial growth after two days of incubation was recorded as minimum bactericidal concentration (Aibinu et al., 2007).

Antibiotics susceptibility testing of the test organism: Antimicrobial disc tests of the isolates were performed according to the guidelines of Kirby-Bauer disk diffusion susceptibility test protocol (Hudzicki,2009) using the following antibiotic discs: Nitrofurantoin (20ug), Amoxicillin (30ug), Rocephin (25ug), Ciprofloxacin (10ug), Augmentin (20ug), Gentamicin (10ug), Tetracycline (30ug), Chloramphenicol (25ug), Cefuroxime (10ug), Ampicillin (30ug), and Ofloxacin (30ug), and antibiotics resistance was interpreted by diameter of inhibition zones around the antibiotic discs.

Qualitative phytochemical screening: The qualitative phytochemical screening was conducted using the following analytical methods; for the analysis of tannins and alkaloid, the method used was the method of Treas and Evans (1996) and Kanoman et al. (2014), while saponins, glycoside, carbohydrates, sugars and terpenoid were studied using the method as described by Harbourne (1984). Anthraquinone was analysed using methods described by Auwal et al. (2014). Steroids and acidic compounds were analysed using the methods described by Akpuaka (2009).

Data analysis: The results were presented as the mean \pm SEM (standard error of mean) for each of the experiments. The test groups were compared with the negative and positive control groups using one-way analysis of variance (ANOVA) by means of Sigma Stat, Graph pad prism (Graphpad software, San Diego, $\mathrm{CA})$. All data were analysed at a $95 \%$ confidence interval. P- values less than 0.05 were considered statistically significant.

\section{RESULTS AND DISCUSSION}

Phytochemical screening: Phytochemical screening of the flower of L. trifolia yielded nine (9) phytochemicals in both ethanolic and aqueous extracts. They include flavonoids, tannins, phenylethanoid glycosides reducing sugars, terpenoids, saponins, anthraquinones, alkaloids, and steroids (Table 1). Souza and Costa (2012) reported the presence of terpenoids, flavonoids, phenylethanoid glycosides, alkaloids, and tannins in Lantana sp., while Nalubega et al. (2013), reported the presence of flavone and glycosides in L. trifolia.

Table 1: Phytochemical analysis of ethanol and aqueous extracts

\begin{tabular}{lll}
\multicolumn{3}{c}{ of L.trifolia } \\
\hline Phytochemicals & Ethanol & Aqueous \\
\hline Flavonoids & +++ & +++ \\
Tannins & ++ & + \\
Phenylethanoid glycosides & ++ & + \\
Reducing sugars & + & + \\
Terpenoids & +++ & +++ \\
Saponins & ++ & ++ \\
Anthraquinones & + & + \\
Alkaloids & ++ & ++ \\
Steroids & + & + \\
\hline - & Slightly present; ++ moderately present; $+++=$ \\
\multicolumn{3}{c}{ present. }
\end{tabular}

Tannins, alkaloids, and phenylethanoid glycosides, were highly present in the ethanolic than aqueous extract. The dissolution capacity of the different solvents affects the level of the phytochemicals extracted. Ethanol has a higher dissolution capacity than distilled water, as confirmed by the higher degree of the presence of some phytochemicals. The cytotoxic, antimicrobial and medicinal activities of these isolated phytochemicals have been well documented (Souza and Costa, 2012; Afidati, 2019). For instance, terpenoids, alkaloids and saponins are known to cause degradation of cytoplasmic membrane, both in function and structure. Damaging the cytoplasmic membrane which causes cytoplasm coagulation and increased membrane permeability leading to leakages of vital intracellular substances and reducing ATP synthesis (De Olivera et al., 2013; Afidati, 2019). This process leads to cell death. Terpenoids can also cause large scale membrane thinning on lipid bilayer and exert antimicrobial properties via a membrane disruption mechanism. Consequently, terpenoids show significant pharmacological activities, such as anti-viral, antibacterial, anti-malarial, anti-inflammatory, inhibition of cholesterol synthesis and anti-cancer activities (Souza and Costa, 2012). L. trifolia is rich in terpenoids as indicated in this study.

These properties make L. trifolia the ideal candidate for a novel plant-based antibacterial drug. Flavonoids inhibit membrane bound enzymes. This attribute may explain the antioxidant application of L. trifolia, locally practiced by indigenous cultures in Africa (Nalubega, 2013; Alonygudet et al., 2017), while phenylethanoid glycosides, which are antibacterial, 
antitumor, antiviral, anti-inflammatory, neuroprotective, antioxidant (Ge et al.,2017; Kutluay et al., 2019).Tannins' antimicrobial activity is based on its ability to inhibit membrane bound enzymes (Anderson et al., 2012).

Table 2: Bacteria isolates, number and percentage of occurrence

\begin{tabular}{lll}
\hline Bacterial Isolates & $\begin{array}{l}\text { Number of } \\
\text { Occurrence per } \\
\text { sample }\end{array}$ & $\begin{array}{l}\% \\
\text { Occurrence }\end{array}$ \\
\hline Staphylococcus aureus & 51 & 42.5 \\
Staphylococcus epidermidis & 10 & 8.33 \\
Enterococcus faecalis & 5 & 4.17 \\
Corynebacterium sp. & 3 & 2.5 \\
Enterobacter aerogenes & 2 & 1.7 \\
Pseudomonas aeruginosa & 30 & 25 \\
Mycobacterium sp. & 4 & 3.33 \\
Escherichia coli & 15 & 12.5 \\
\hline
\end{tabular}

Morphological and biochemical characteristics of bacterial isolates: The screening of wounds for bacteria produced eight (8) bacteria. They include
Staphylococcus aureus, S. epidermidis, Enterococcus faecalis, Corynebacterium sp., Enterobacter aerogenes, Pseudomonas aeruginosa, Mycobacterium sp. and Escherichia coli. Of the bacterial isolates collected per sample, $S$. aureus occurred in the highest number of patients $(42.5 \%)$, while E. aerogenes occurred in the lowest number (1.7\%) (Table 2).

A single etiologic agent was found in 80 , multiple agents were found in 40 patients. Gram positive bacteria dominated the infected wounds. The gram positive bacteria were S. aureus, S. epidermidis, E. faecalis, Corynebacterium sp., while E.aerogenes, $P$. aeruginosa, E. coli were gram-ve bacteria. Mycobacterium sp. was an acid fast bacterium (Table $3)$. This does not agree with the report by Oshilim (2017), who isolated more gram -ve bacteria than gram +ve from wounds. Majority of the bacteria were also rods (6), as against the very few (2) cocci.

Table 3: Morphological and biochemical characteristics of the bacteria isolates.

\begin{tabular}{|c|c|c|c|c|c|c|c|c|}
\hline $\begin{array}{l}\text { Test and } \\
\text { Assessment }\end{array}$ & $\begin{array}{l}S . \\
\text { aureus }\end{array}$ & $\begin{array}{l}\text { S. } \\
\text { epidermidis }\end{array}$ & $\begin{array}{l}\text { E. } \\
\text { faecalis }\end{array}$ & $\begin{array}{l}\text { Corynebacterium } \\
\text { sp. }\end{array}$ & $\begin{array}{l}\text { E. } \\
\text { aerogenes }\end{array}$ & $\begin{array}{l}P . \\
\text { aeruginosa }\end{array}$ & $\begin{array}{l}\text { Mycobacterium } \\
\text { sp. }\end{array}$ & E. coli \\
\hline Gram stain & GPC & GPC & GPB & GPB & GNB & GNB & $\begin{array}{l}\text { Acid fast } \\
\text { bacilli }\end{array}$ & GNB \\
\hline $\begin{array}{l}\text { Morphological } \\
\text { characteristics }\end{array}$ & Cocci & Cocci & Rods & Rods & Rods & Rods & Rods & Rods \\
\hline Citrates & - & - & + & - & + & + & + & - \\
\hline Oxidase & - & - & - & - & - & + & - & - \\
\hline Catalase & + & + & + & + & + & + & + & - \\
\hline Indole & + & + & _ & - & - & - & - & + \\
\hline Glucose & + & + & $\overline{+}$ & + & + & - & + & + \\
\hline Lactose & + & + & + & - & + & - & + & + \\
\hline $\mathrm{H}_{2} \mathrm{~S}$ & - & - & - & - & - & - & - & + \\
\hline Gas & - & - & - & + & - & - & - & + \\
\hline
\end{tabular}

Table 4: Antibacterial activity of flower extracts of $L$. trifolia (zones of inhibition are measured in millimetres, $\mathrm{mm}$ )

\begin{tabular}{|c|c|c|c|c|c|c|c|c|c|}
\hline $\begin{array}{l}\text { Drug/ } \\
\text { Extracts }\end{array}$ & $\begin{array}{l}\text { Concentration } \\
\mathrm{s}(\mathrm{mg} / \mathrm{ml})\end{array}$ & S. aureus & $\begin{array}{l}S . \\
\text { epidermidis }\end{array}$ & E. faecalis & $\begin{array}{l}\text { Corynebacterium } \\
\text { sp. }\end{array}$ & $\begin{array}{l}\text { E. } \\
\text { aerogenes }\end{array}$ & $\begin{array}{l}P . \\
\text { aeruginosa }\end{array}$ & $\begin{array}{l}\text { Mycobacterium } \\
\text { sp. }\end{array}$ & E. coli \\
\hline \multirow[t]{6}{*}{ Ethanolic } & $\begin{array}{l}\text { Ethanol(-ve } \\
\text { control) }\end{array}$ & $0.0 \pm 0.0^{\mathrm{a}}$ & $0.0 \pm 0.0^{\mathrm{a}}$ & $0.2 \pm 0.0^{\mathrm{a}}$ & $0.5 \pm 0.1^{\mathrm{a}}$ & $0.0 \pm 0.0^{\mathrm{a}}$ & $0.0 \pm 0.0^{\mathrm{a}}$ & $0.0 \pm 0.0^{\mathrm{a}}$ & $0.0 \pm 0.0^{\mathrm{a}}$ \\
\hline & 300 & $49.1 \pm 8.9^{\mathrm{b}}$ & $38.1 \pm 5.1^{\mathrm{c}}$ & $39.2 \pm 5.8^{\mathrm{c}}$ & $30.3 \pm 1.5^{\mathrm{c}}$ & $36.8 \pm 1.8^{c}$ & $30.2 \pm 5.2^{\mathrm{c}}$ & $28.3 \pm 3.4^{\mathrm{c}}$ & $34.5 \pm 3.1^{\mathrm{c}}$ \\
\hline & 150 & $28.5 \pm 5.6^{\mathrm{c}}$ & $21.3 .1 \pm 3.2^{\mathrm{d}}$ & $23.4 \pm 5.2^{\mathrm{d}}$ & $21.2 \pm 2.2^{\mathrm{d}}$ & $23.4 \pm 2.6^{\mathrm{d}}$ & $27.2 \pm 1.7^{\mathrm{d}}$ & $15.1 \pm 2.5^{\mathrm{e}}$ & $24.2 \pm 2.6^{\mathrm{d}}$ \\
\hline & 75 & $19.2 \pm 0.0^{\mathrm{e}}$ & $13.1 \pm 2.6^{\mathrm{e}}$ & $18.1 \pm 6.1^{\mathrm{e}}$ & $15.1 \pm 2.6^{\mathrm{e}}$ & $18.4 \pm 2.6^{\mathrm{e}}$ & $18.3 \pm 3.2^{\mathrm{e}}$ & $8.1 \pm 0.0^{\mathrm{f}}$ & $15.3 \pm 0.6^{\mathrm{e}}$ \\
\hline & 37.5 & $9.5 \pm .1 .4^{\mathrm{f}}$ & $5.3 \pm .2 .1^{\mathrm{f}}$ & $7.1 \pm 0.9^{\mathrm{f}}$ & $6.2 \pm 3.2^{\mathrm{f}}$ & $6.2 \pm 1.2^{\mathrm{f}}$ & $6.1 \pm 1.1^{\mathrm{f}}$ & $7.6 \pm 1.4^{\mathrm{f}}$ & $9.3 \pm 0.6^{\mathrm{f}}$ \\
\hline & 18.75 & $0.0 \pm 0.0^{\mathrm{a}}$ & $0.0 \pm 0.0^{\mathrm{a}}$ & $0.0 \pm 0.0^{\mathrm{a}}$ & $0.0 \pm 0.0^{\mathrm{a}}$ & $4.2 \pm 0.6^{\mathrm{f}}$ & $0.0 \pm 0.0^{\mathrm{a}}$ & $0.0 \pm 0.0^{\mathrm{a}}$ & $6.0 \pm 0.0^{\mathrm{f}}$ \\
\hline \multirow[t]{6}{*}{ Aqueous } & $\begin{array}{l}\text { Distilled water } \\
\text { (-ve Control }\end{array}$ & $0.0 \pm 0.0^{\mathrm{f}}$ & $0.0 \pm 0.0^{\mathrm{a}}$ & $0.1 .0 \pm 0.0^{\mathrm{f}}$ & $0.2 \pm 0.0^{\mathrm{a}}$ & $0.2 \pm 0.0^{\mathrm{a}}$ & $0.0 \pm 0.0^{\mathrm{a}}$ & $0.0 \pm 0.0^{\mathrm{a}}$ & $0.0 \pm 0.0^{\mathrm{a}}$ \\
\hline & 300 & $35.5 \pm 0.9^{c}$ & $24.6 \pm 3.1^{\mathrm{d}}$ & $24.3 \pm 2.8^{\mathrm{d}}$ & $15.2 \pm 1.5^{\mathrm{e}}$ & $18.1 \pm 0.8^{\mathrm{e}}$ & $20.1 \pm 2.4^{\mathrm{d}}$ & $21.8 \pm 3.2^{\mathrm{d}}$ & $28.5 \pm 3.1^{\mathrm{d}}$ \\
\hline & 150 & $18.6 \pm 1 .^{6 \mathrm{~d}}$ & $16.3 . \pm 3.2^{\mathrm{d}}$ & $18.4 \pm 5.2^{\mathrm{d}}$ & $9.2 \pm 0.2^{\mathrm{f}}$ & $11.3 \pm 2.6^{\mathrm{e}}$ & $11.1 \pm 0.5^{\mathrm{e}}$ & $13.2 \pm 0.7^{\mathrm{e}}$ & $19.2 \pm 2.6^{\mathrm{e}}$ \\
\hline & 75 & $7.0 \pm 0.0^{\mathrm{e}}$ & $10.1 \pm 2.6^{\mathrm{e}}$ & $4.0 \pm 0.0^{f}$ & $0.0 \pm 0.0^{\mathrm{a}}$ & $0.0 \pm 0.0^{\mathrm{a}}$ & $5.1 \pm 0.1^{\mathrm{f}}$ & $5.6 \pm 2.2^{\mathrm{f}}$ & $11.3 \pm 0.6^{\mathrm{e}}$ \\
\hline & 37.5 & $0 \pm .0 .0^{\mathrm{a}}$ & $8.3 \pm .2 .1^{\mathrm{e}}$ & $0 \pm 0.0^{\mathrm{a}}$ & $0.0 \pm 0.0^{\mathrm{a}}$ & $0.0 \pm 0.0^{\mathrm{a}}$ & $0.0 \pm 0.0^{\mathrm{a}}$ & $2.1 \pm 0.1^{\mathrm{a}}$ & $5.3 \pm 0.6^{\mathrm{f}}$ \\
\hline & 18.75 & $0.0 \pm 0.0^{\mathrm{a}}$ & $0.0 \pm 0.0^{\mathrm{a}}$ & $0.0 \pm 0.0^{\mathrm{a}}$ & $0.0 \pm 0.0^{\mathrm{a}}$ & $0.0 \pm 0.0^{\mathrm{a}}$ & $0.0 \pm 0.0^{\mathrm{a}}$ & $0.0 \pm 0.0^{\mathrm{a}}$ & $0.0 \pm 0.0^{\mathrm{a}}$ \\
\hline $\begin{array}{l}\text { Ciproflox } \\
\text { acin (+ve } \\
\text { control) }\end{array}$ & $1 \%$ solution & $32.6 \pm 1.0^{\mathrm{c}}$ & $25.03 \pm 2.1^{\mathrm{d}}$ & $\begin{array}{l}25.2 .1 \pm 3 . \\
2^{\mathrm{d}}\end{array}$ & $25.5 \pm 2.6^{\mathrm{d}}$ & $18.2 \pm 2.5^{\mathrm{e}}$ & $23.3 \pm 6.1^{\mathrm{d}}$ & $18.8 \pm 3.4^{\mathrm{e}}$ & $26.3 \pm 7.1^{\mathrm{d}}$ \\
\hline
\end{tabular}

Mean values with different alphabets as superscripts in a column differ significantly $(P<0.05)$. 
Antimicrobial activity of plant extracts: The antibacterial effects of the extracts is shown in Table 4.Both aqueous and ethanolic extracts of L. trifolia flower showed antibacterial activity. The inhibition diameter of both aqueous and ethanolic extracts were significantly $(\mathrm{P}<0.05)$ higher than those of the negative controls, especially at high concentrations. Antibacterial activity of $L$. trifolia, was significantly $(\mathrm{P}<0.05)$ dependent on the nature of the solvent used for extraction and the concentration of the extracts. At the highest concentration $(300 \mathrm{mg} / \mathrm{ml})$, inhibition zone diameter range was significantly $(\mathrm{P}<0.05)$ greater in the ethanolic extract $(28.3 \pm 3.4$ to $49.1 \pm 8.9 \mathrm{~mm})$ than the aqueous extract $(15.2 \pm 1.5$ to $35.5 \pm 0.9 \mathrm{~mm})$. The potency of $L$. trifolia was enhanced by the type of solvent used during the extraction process. Ethanol extracted more of the bioactive components of the plants, when compared with the aqueous extract. Both ethanolic and aqueous extracts exhibited nonselective antibacterial activity against the isolates. $S$. aureus was the most sensitive bacteria in both solvents with the widest inhibition diameter range for the ethanolic extract from $9.5 \pm .1 .4 \mathrm{~mm}$ at $37.5 \mathrm{mg} / \mathrm{ml}$ to $49.1 \pm 8.9 \mathrm{~mm}$ and the least sensitive was Mycobacterium sp. from $7.6 \pm 1.4 \mathrm{~mm}$ at $37.5 \mathrm{mg} / \mathrm{ml}$ to $28.3 \pm 3.4 \mathrm{~mm}$ at $300 \mathrm{mg} / \mathrm{ml}$. For the aqueous extracts, the same bacteria $S$. aureus exhibited a lower inhibition diameter range from $7.0 \pm 0.0$ at75 $\mathrm{mg} / \mathrm{ml}$ to $35.5 \pm 0.9 \mathrm{~mm}$ at $300 \mathrm{mg} / \mathrm{ml}$, and the least sensitive was Corynebacterium sp. with an inhibition zone diameter of $9.2 \pm 0.2 \mathrm{~mm}$ at $150 \mathrm{mg} / \mathrm{ml}$ to $15.2 \pm 1.5$ at $300 \mathrm{mg} / \mathrm{ml}$ ) (Table 4).

At the highest concentration $(300 \mathrm{mg} / \mathrm{ml})$, all the isolated test organisms, were significantly $(\mathrm{P}<0.05)$ more sensitive to the ethanolic extract, haven registered higher inhibition zone diameters than Ciprofloxacin. However, for the aqueous extract, only $S$. aureus and $E$. coli were significantly $(\mathrm{P}<0.05)$ more sensitive to the extract than the reference antibiotics, with a higher inhibition zone diameter ( $35.5 \pm 0.9$ and $28.5 \pm 3.1 \mathrm{~mm})$ for $S$. aereus and E. coli respectively)than Ciprofloxacin (32.6. \pm 1.0 and $26.3 \pm 7.1$ for $S$. aureus and E. coli). All the other isolates, S. epidermidis, E. faecalis Corynebacterium sp., E. aerogenes, $P$. aeruginosa, and Mycobacterium sp.had inhibition diameters $(\geq 15 \mathrm{~mm})$, lower than those exhibited by the isolates in the antibiotics $(\geq$ $18 \mathrm{~mm})$. Though, this is a further confirmation of the higher potency of the ethanolic extract to the aqueous extract, this value indicates that the aqueous flower $L$. trifolia extract is also an efficient antibiotics. Any antimicrobial agent showing an Inhibition zone diameter of $\geq 15 \mathrm{~mm}$ on a microorganism is an efficient antimicrobial agent (Hudzicki, 2009). The minimum inhibition concentration (MIC) and minimum bacterial concentration $(M B C)$ : Isolates were highly sensitive to ethanolic extract of $L$. trifolia with MIC ranging from $18.75 \mathrm{mg} / \mathrm{ml}$ (E. coli and $E$. aerogenes) to $37.5 \mathrm{mg} / \mathrm{ml}$ (the rest of the isolates).On the other hand, Isolates were moderately sensitive to aqueous extract of $L$. trifolia with MIC ranging from 37.5 (E. coli and Mycobacterium sp) to $150 \mathrm{mg} / \mathrm{ml}$ (Corynebacterium sp. and E. aerogenes). MBC for the ethanolic flower extract, ranged from 37.5 (E. coli and E. aerogenes) to $75 \mathrm{mg} / \mathrm{ml}$ (rest of the isolated test organisms), for the aqueous extract, MBC was higher than that reported for the ethanolic extract and ranged from 75(S. epidermidis, E. faecalis, Mycobacterium and E. coli) to $300 \mathrm{mg} / \mathrm{ml}$ (Corynebacterium sp.) (Figure1).



Fig 1. Minimum inhibitory concentration (MIC) and Minimum bactericidal concentration (MBC) of isolates to flower ethanolic and aqueous extracts of $L$. trifolia

The results from this study revealed that flower of $L$. trifolia has antimicrobial properties and therefore is a medicinal plant (Nalubega et al., 2012). This report agrees with Salada et al. (2015) and Sharma et al. (2013), who reported that Lantana sp has antimicrobial properties. Ethanolic and aqueous 
extracts of $L$. trifolia exhibited a non-selective bacteriostatic activity. The extracts exhibited antibacterial activity against both gram +ve and gram -ve bacteria making them broad spectrum. The study also revealed that $S$. aureus has a high tendency to develop resistance to antimicrobial agents. S. aureaus with very wide inhibition zone diameter for both aqueous and ethanolic extracts (indicates high sensitivity to the extract), however, it also had very high MIC and MBC, (indicating low sensitivity to the extract as well). These two opposing attributes indicative resistance tendency. There is need to treat $S$. aureus infections with various kinds of antibiotics, alternated after a given period of time in that environment. This is to prevent antibiotics resistance through drug pressure in $S$. aureus.
Antibiotics sensitivity: The bacterial isolates were screened for antibiotics sensitivity and exhibited varying degrees of antibiotics resistance as presented in Table 10. Eleven (11) different antibiotics were used and the organisms were selectively resistant to the antibiotics. The most resistant bacterium strain was S. aureus (72.7\%), while the least resistant were $P$. aeruginosa and Mycobacterium sp. (9.1\%). The most effective antibiotics were ciprofloxacin and Rocephin, while the least effective was tetracycline, with all isolates resistant to it (Table 5). The organisms were resistant due to plasmid borne or chromosomally mediated resistance (Munita and Arias, 2016). Comparatively, L. trifolia extracts were more potent antibacterial substance than the conventional antibiotics.

\begin{tabular}{|c|c|c|c|c|c|c|c|c|}
\hline Antibiotics & $\begin{array}{l}\text { E. } \\
\text { coli }\end{array}$ & $\begin{array}{l}\text { Mycobacterium } \\
\text { sp. }\end{array}$ & $\begin{array}{l}S . \\
\text { epidermidis }\end{array}$ & $\begin{array}{l}E . \\
\text { faecalis }\end{array}$ & $\begin{array}{l}\text { Corynebacterium } \\
\text { sp. }\end{array}$ & $\begin{array}{l}\text { E. } \\
\text { aerogenes }\end{array}$ & $\begin{array}{l}P . \\
\text { aeruginosa }\end{array}$ & $\begin{array}{l}s \\
\text { aureus }\end{array}$ \\
\hline Nitrofurantion & ++ & +++ & +++ & +++ & + & + & + & $\mathrm{R}$ \\
\hline Ciprofloxacin & +++ & +++ & ++ & ++ & ++ & +++ & ++ & + \\
\hline Tetracycline & $\mathrm{R}$ & $\mathrm{R}$ & $\mathrm{R}$ & $\mathrm{R}$ & $\mathrm{R}$ & $\mathrm{R}$ & $\mathrm{R}$ & $\mathrm{R}$ \\
\hline Amoxicillin & $\mathrm{R}$ & +++ & $\mathrm{R}$ & ++ & $\mathrm{R}$ & ++ & + & + \\
\hline Ofloxacin & ++ & +++ & + & $\mathrm{R}$ & $\mathrm{R}$ & $\mathrm{R}$ & ++ & $\mathrm{R}$ \\
\hline Chloramphenicol & + & + & $\mathrm{R}$ & $\mathrm{R}$ & + & ++ & + & $\mathrm{R}$ \\
\hline Cefuroxine & $\mathrm{R}$ & + & + & ++ & $\mathrm{R}$ & + & + & $\mathrm{R}$ \\
\hline Ampicillin & $\mathrm{R}$ & + & $\mathrm{R}$ & + & + & $\mathrm{R}$ & ++ & $\mathrm{R}$ \\
\hline Gentamicin & $\mathrm{R}$ & +++ & + & ++ & ++ & ++ & + & $\mathrm{R}$ \\
\hline Augumentin & $\mathrm{R}$ & +++ & $\mathrm{R}$ & + & + & + & + & $\mathrm{R}$ \\
\hline Rocephin & + & + & + & + & $\mathrm{R}$ & + & ++ & ++ \\
\hline Resistance \% & 55.0 & 9.1 & 46.0 & 27.3 & 46.0 & 27.3 & 9.1 & 72.2 \\
\hline
\end{tabular}

Conclusion: This study revealed that the flower of $L$. trifolia is a highly potent bacteriostatic plant, whose potency was enhanced using ethanol as the extraction medium. In addition, the ethanolic extract of the plant at $300 \mathrm{mg} / \mathrm{ml}$ concentration, achieved antibacterial activity even higher than that of the reference antibiotics Cyprofloxacin tested. L. trifolia is an antimicrobial pointer to new sources of novel drugs which merits further investigation.

\section{REFERNCES}

Afidati, S (2019). Inhibition of water hyacinth leaf extract (Echhornia. crussipes) against Aggregatibacter actinomycetemcomitans. Asian J. of Pharm. and Clinic. Res. 12 (6) 122125.

Aibinu, I; Adenipekun, T; Adelowowtan, T; Ogunsanya, T; Odugbemi, T (2007). Evaluation of the antimicrobial properties of different parts of Citrus aurantifolia (lime fruit) as used locally. Afr. J. Tradit. CAM. 2: 185-190.

Akpuaka, MU (2009). Essential of Natural Product Chemistry. Mason Publishers; Enugu. pp. 47.
Anderson, RB; Vodonik, M; Min, B and Pinchak, WE (2012). Bactericidal effect of hydrolysable and condensed tannin extracts on Campylobacter jejuni in vitro. Folia Microbiologica 57(4):253-8.

Auwal, MS; Saka,S ; Mairiga, A ; Sanda ,KA; Shuaibu, A; Ibrahim, A (2014).Preliminary phytochemical and elemental analysis of aqueous and fractionated pod extracts of Acacia nilotica (Thorn mimosa). Vet. Res. Forum 5(2): 95-100.

De Oliveira, CB; Comunello, LN; Maciel, ES; Giubel, SR; Bruno, AN; Chiela, ECF ; Guido, L; Gnoatto, CB; Buffon, A; Gosmann, G (2013). The inhibitory effects of phenolic and terpenoid compounds from Baccharis trimera in Siha Cells: Differences in their activity and mechanism of action. Molecules 18, 11022-11032.

Evbuomwan, L; Chukwuka, EP; Obazenu, EI; Ilevbare, L (2017). Antibacterial Activity of Vernonia amygdalina Leaf Extracts against 
Multidrug Resistant Bacterial Isolates. J. Appl. Sci. Environ. Manage. 22 (1) 17-21.

Ge, L; Zhang, E; Zhou, G; Ma, B; Mo, Q; Chen, Y; Wang, Y (2017). Nine phenylethanoid glycosides from Magnolia officinalis var. biloba fruits and their protective effects against free radicalinduced oxidative damage. Sci. Rep. 7, 45342; doi: 10.1038/ srep45342; Springer Nature.

Giacometti, A; Cirioni, O ; Schimizzi, AM ; Del Prete, MS ; Barchiesi, F; D’errico, MM ; Petrelli, E; Scalise, G (2000)._Epidemiology and microbiology of surgical wound infections. $J$. of Clinic. Microbiol. 38 (2): 2918-922.

Harbourne, JB (1984). Phytochemical methods: a guide to modern techniques of plant analysis, 2nd ed. Chapman and Hall, London.

Hudzicki, J (2016). Kirby-Bauer Disk Diffusion Susceptibility Test Protocol. American Society for Microbiology. https://www.asm.org.

Idris, S; Ndukwe, GI; Gimba, CE (2009). Preliminary phytochemical screening and antimicrobial activity of seed extract of persea Americana (avocado pear). Bayero J. Pure Appl. Sci. 2(1): $173-176$.

Kutluay, VM; Ishiuchi, K; Makino, T; Saracoglu, I (2019).Cytotoxic phenylethanoid glycosides from Digitalis davisiana Heywood: Evaluation of structure activity relationships and chemotaxonomical significance of isolated compounds. Fitoterapia 135:90-98.

Mohammed, A; Adeshina, GO; Ibrahim, YKE (2013).Retrospective incidence of wound infections and antibiotic sensitivity pattern: A study conducted at the Aminu Kano Teaching Hospital, Kano, Nigeria. Int. J. of Med. and Medical Sci. 5(2): 60-66.
Munita, JM; Arias, CA (2016). Mechanisms of antibiotic resistance. Microbiol. Spectrum 4(2):120.

Nalubega, RSA; Nyanzi, SAN; Nakavuma, JL; Kamatensi-Mugisha, M (2013).Ethnobotanical uses of Lantana trifolia and Sida cuneifolia Roxb. In Mukungwe and Wabinyonyi sub-counties of central Uganda. J. of Intercultural Ethnopharmacology 2(3):155-164.

Okigbo, RN; Mmeka, EC (2008). Antimicrobial effects of three tropical plant extracts on Staphylococcus aureus, Escherichia coli and Candida albicans Afr. J. Trad. Cam. 5 (3): 226 $-229$.

Oshilim, AO (2017). Comparative study of the effect of bitter leaf extract and antibiotics (gentamycin and amoxicillin) on bacterial species isolated from wound. J. of Biotech. Pharm. Res. 6 (1):09012.

Preethi, RM; Devanathan, VV; Loganathan, M (2010). Antimicrobial and antioxidant efficacy of some medicinal plants against food borne pathogens. Adv. Biol. Res. 4: 122-125.

Salad, JT; Bala, LM; Vasquez, EA (2015). Phytochemical and Antibacterial Studies of Lantana camara L. Leaf Fraction and essential Oil. Intl. J. of Sci. and Res. Publs., 5 (3):1-5

Sharma, P; Shrivastava, B; Sharma, GN; Jadhave, HR (2013). Phytochemical and Pharmacological profile of Lantana camara L: An Overview. J. of adv. Phar. Edu. Res. 3 (4):294-305.

Sousa, EO; Costa, JGM (2012). Genus Lantana: chemical aspects and biological activities. Revista Brasileira de Farmacognosia 22 (5): 1155-1180.

Trease, EN; Evans, WC (1996). Pharmacognosy, $13^{\text {th }}$ edition, Buddiertindall, London. 